\title{
Uji efek ekstrak biji alpukat (Persea americana Mill.) terhadap kadar kolesterol total pada tikus wistar (Rattus norvegicus)
}

\author{
${ }^{1}$ Abraham T. Suhendra \\ ${ }^{2}$ Henoch Awaloei \\ ${ }^{2}$ Jane Wuisan
}

\author{
${ }^{1}$ Kandidat Skripsi Fakultas Kedokteran Universitas Sam Ratulangi Manado \\ ${ }^{2}$ Bagian Farmakologi dan Terapi Fakultas Kedokteran Universitas Sam Ratulangi Manado \\ Email: abrahamsuhendra12086@gmail.com
}

\begin{abstract}
Indonesia is a tropical country that has more than 1,000 kinds of medicinal plants. Medicinal plant is the use of part(s) of plants as ingredients in traditional medicine or synthetic drugs. One of the traditional medicine is avocado. Several studies have concluded that the avocado fruit and leaves can reduce total blood cholesterol levels while the seed is used in Nigeria for treating hypertension. This was an experimental study. Samples consisted of 12 male Wistar rats, divided into 4 groups (3 rats in each group). The treated groups were given propylthiouracil (PTU) for 14 days then the rats were given $125 \mathrm{mg} / \mathrm{kg}$ or $250 \mathrm{mg} / \mathrm{kg}$ of avocado seed extract for 14 days. The positive control group was given PTU $8 \mathrm{mg} /$ rat for 14 days, followed by simvastatin $0.2 \mathrm{mg}$ for 14 days. The negative control group was only given food and water. The results showed that the average level of total blood cholesterol in Wistar rats after treated with $125 \mathrm{mg} / \mathrm{kg}$ and $250 \mathrm{mg} / \mathrm{kg}$ avocado seed extract decreased by $18.1 \%$ and $31.2 \%$, respectively. Conclusion: Avocado seed extract had an effect in reducing total blood cholesterol of Wistar rats.
\end{abstract}

Keywords: avocado seed, total cholesterol level

\begin{abstract}
Abstrak: Indonesia merupakan salah satu negara tropis yang memiliki banyak tumbuhan dimana lebih dari 1000 tumbuhan tersebut dapat digunakan sebagai tanaman obat. Tanaman obat ialah penggunaan bagian dari tanaman atau tumbuhan sebagai bahan dalam pembuatan obat tradisional maupun obat sintetik. Salah satu tanaman yang digunakan sebagai obat tradisional ialah alpukat. Beberapa penelitian mengenai tanaman alpukat menunjukkan bahwa buah dan daun dari tanaman Alpukat dapat menurunkan total kolesterol dalam darah, sedangkan biji alpukat digunakan di Nigeria sebagai pengobatan untuk hipertensi. Penelitian ini menggunakan metode eksperimental. Sampel ialah 12 ekor tikus Wistar jantan yang dibagi menjadi 4 kelompok (setiap kelompok terdiri dari 3 tikus). Kelompok-kelompok perlakuan diberikan propiltiourasil (PTU) selama 14 hari kemudian diberikan $125 \mathrm{mg} / \mathrm{kg}$ atau $250 \mathrm{mg} / \mathrm{kg}$ ekstrak biji Alpukat selama 14 hari. Kelompok kontrol positif diberikan PTU selama 14 hari kemudian diberikan simvastatin $0,20 \mathrm{mg} / \mathrm{kg}$ selama 14 hari. Kelompok kontrol negatif hanya diberikan pakan dan air. Hasil penelitian memperlihatkan rerata kadar kolesterol total tikus Wistar setelah diberikan $125 \mathrm{mg} / \mathrm{kg}$ dan $250 \mathrm{mg} / \mathrm{kg}$ ekstrak biji alpukat menurun sebesar 18,1\% dan 31,2\%. Simpulan: Ekstrak biji Alpukat berefek menurunkan kadar kolesterol total pada tikus Wistar.
\end{abstract}

Kata kunci: biji alpukat, kadar kolesterol total

Indonesia merupakan salah satu negara tropis yang memiliki banyak keanekaragaman hayati. Indonesia memiliki sekitar
25.000 - 30.000 jenis tumbuhan dimana jumlah tersebut mencakup 90\% dari jumlah tumbuhan di Asia. Dari jumlah 
tersebut, lebih dari 1000 tumbuhan dapat digunakan sebagai tanaman obat. ${ }^{1-3}$

Tanaman obat ialah bagian dari tumbuhan bisa berupa daun, batang, buah, bunga atau akarnya yang memiliki khasiat yang dapat menyembuhkan suatu penyakit dan digunakan secara turun-temurun oleh masyarakat di wilayah tertentu dan tanaman ini yang nanti akan disebut sebagai obat tradisional. ${ }^{3}$ Obat tradisional ialah suatu bahan yang dapat berupa bahan tunggal atau campuran dari berbagai bahan bisa berasal dari tumbuhan, hewan, mineral, yang berdasar dari pengalaman secara turun-temurun telah digunakan untuk menyembuhkan suatu penyakit. Sebagian besar obat tradisional berasal dari tanaman obat karena pada kenyataannya bahan obat tradisional yang sering digunakan lebih banyak berasal dari tumbuhan daripada hewan atau mineral sehingga dapat dikatakan bahwa obat tradisional memiliki keterkaitan yang erat dengan tanaman obat. ${ }^{1,4,5}$

Salah satu tumbuhan yang digunakan sebagai obat tradisional ialah alpukat., ${ }^{6,7}$ Penelitian mengenai tanaman alpukat menunjukkan bahwa buah dan daun nya memiliki khasiat untuk menurunkan kadar kolesterol total serta memiliki efek dalam menghambat pertumbuhan bakteri, ${ }^{8-11}$ sedangkan biji alpukat digunakan sebagai obat di Nigeria dalam mengobati orang yang bertekanan darah tinggi. ${ }^{12}$

Penelitian ini bertujuan untuk mendapatkan pengaruh biji alpukat terhadap kadar kolesterol total pada tikus Wistar.

\section{METODE PENELITIAN}

Penelitian ini menggunakan metode eksperimental dengan pretest-posttest design yang dilakukan di Laboratorium Farmakologi dan Terapi serta Animal House Fakultas Kedokteran Universitas Sam Ratulangi Manado pada bulan September 2015 - Januari 2016.

Subjek penelitian ialah 12 ekor tikus Wistar jantan dengan berat badan 200 g.

\section{Alat dan Bahan}

Ekstrak biji alpukat dibuat dengan menggunakan etanol $80 \%$ Kadar kolesterol diukur dengan Autocheck Electronic Blood Cholesterol Test.

Bahan-bahan yang digunakan ialah biji alpukat 500 g, akuades $100 \mathrm{ml}$, simvastatin tablet $20 \mathrm{mg}$, pakan AD2, dan propiltiourasil tablet $100 \mathrm{mg}$.

Tikus Wistar yang digunakan diinduksi dengan propiltiourasil, kemudian diberikan ekstrak biji alpukat.

\section{Penentuan dosis propiltiourasil (PTU)}

Dosis rentang PTU untuk orang dewasa dengan berat badan rata-rata $50 \mathrm{~kg}$ adalah 500-2.000 mg. Dosis yang digunakan dalam penelitian ini ialah 2.000 mg. Dosis yang digunakan pada tikus dengan berat rata-rata 200 g yaitu: 200 / $50.000 \times 2.000=8 \mathrm{mg} /$ tikus/hari. PTU dibuat dalam bentuk larutan dengan cara melarutkan satu tablet $100 \mathrm{mg}$ PTU dalam $12,5 \mathrm{ml}$ pelarut (akuades), sehingga dalam $1 \mathrm{ml}$ larutan terkandung $8 \mathrm{mg}$ PTU.

\section{Penentuan dosis simvastatin}

Dosis rentang Simvastatin yang digunakan oleh orang dewasa dengan berat badan rata-rata $50 \mathrm{~kg}$ ialah 5-80 mg. Dalam penelitian ini digunakan dosis 40 mg. Dosis yang digunakan pada tikus dengan berat rata-rata 200 g yaitu: 200/ $50.000 \times 40=0,16$ dibulatkan 0,20 $\mathrm{mg} /$ tikus. Simvastatin dibuat dalam bentuk larutan dengan cara melarutkan satu tablet $20 \mathrm{mg}$ simvastatin dalam $100 \mathrm{ml}$ pelarut aquades, sehingga dalam $1 \mathrm{ml}$ terkandung $0,20 \mathrm{mg}$ simvastatin.

\section{Penentuan dosis ekstrak biji alpukat yang diberikan}

Dosis toksik akut ekstrak biji alpukat ditunjukkan mulai pada dosis 500 $\mathrm{mg} / \mathrm{kgBB}$ sehingga pada penelitian ini digunakan dosis ekstrak biji alpukat 125 $\mathrm{mg} / \mathrm{kgBB}$ tikus dan $250 \mathrm{mg} / \mathrm{kgBB}$ tikus. ${ }^{13}$

Ekstrak biji alpukat, simvastatin, dan PTU diberikan per oral menggunakan sonde lambung metal dan semprit 5 cc. 


\section{Perlakuan hewan uji}

Hewan uji terdiri dari 12 ekor tikus wistar jantan yang dibagi dalam 4 kelompok, yaitu:

1. Kelompok 1 sebagai kontrol negatif, terdiri dari 3 ekor tikus yang hanya diberikan pakan dan akuades ad libitum selama 28 hari.

2. Kelompok 2 sebagai kontrol positif, terdiri dari 3 ekor tikus yang diberikan pakan dan PTU selama 14 hari, lalu diberikan simvastatin sebanyak 0,2 mg/tikus/hari selama 14 hari. Simvastatin diberikan 1 kali sehari pada malam hari.

3. Kelompok perlakuan 1, terdiri dari 3 ekor tikus yang diberikan pakan dan PTU selama 14 hari. Dilanjutkan dengan pemberian ekstrak biji alpukat dengan dosis $125 \mathrm{mg} / \mathrm{kg}$ BB/hari selama 14 hari. Pemberian ekstrak alpukat dilakukan 1 kali sehari pada malam hari.

4. Kelompok perlakuan 2, terdiri dari 3 ekor tikus yang diberikan pakan dan propiltiourasil selama 14 hari. Dilanjutkan dengan pemberian ekstrak biji alpukat dengan dosis $250 \mathrm{mg} / \mathrm{kg}$ BB/hari selama 14 hari. Pemberian ekstrak alpukat dilakukan 1 kali sehari pada malam hari.

\section{Analisis Data}

Data diperoleh dan disajikan secara deskriptif komparatif dengan menilai perbandingan hasil pemeriksaan kadar kolesterol total antara kelompok 1, 2, 3, dan 4. Data disajikan dalam bentuk tabel dan grafik.

\section{HASIL PENELITIAN}

Kadar kolesterol total kelompok 1 disajikan dalam Tabel 1 dan Gambar 1 . Demikian pula untuk kadar kolesterol total kelompok 2 disajikan dalam Tabel 2 dan Gambar 2; untuk kelompok 3 dalam Tabel 3 dan Gambar 3; dan untuk kelompok 4 dalam Tabel 4 dan Gambar 4.
Tabel 1. Kadar Kolesterol Total Tikus Kelompok 1 Sebagai Kontrol Negatif

\section{Hari ke 0 Hari ke $15 \quad$ Hari ke 29}

$(\mathrm{mg} / \mathrm{dL}) \quad(\mathrm{mg} / \mathrm{dL}) \quad(\mathrm{mg} / \mathrm{dL})$

\begin{tabular}{cccc}
\hline Tikus 1 & 105 & 109 & 108 \\
Tikus 2 & 104 & 106 & 105 \\
Tikus 3 & 106 & 108 & 108 \\
\hline Rerata & 105.00 & 107.67 & 107.00 \\
\hline
\end{tabular}

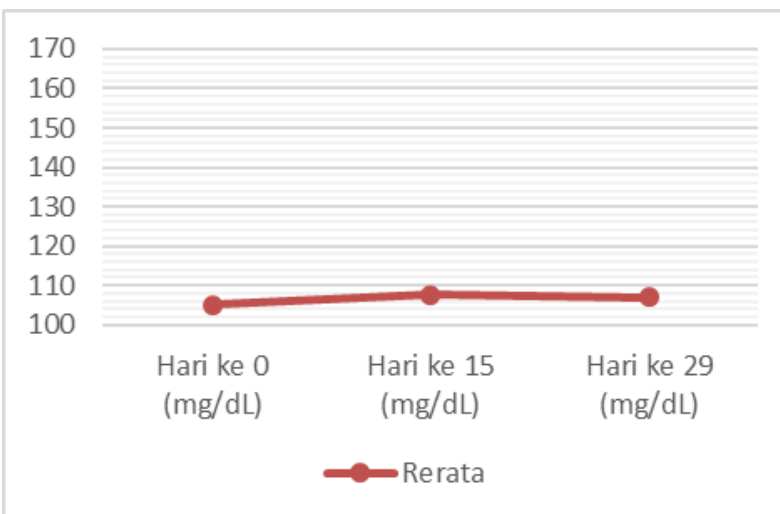

Gambar 1. Grafik Rerata Kadar Kolesterol Total Tikus Kelompok 1

Tabel 2. Kadar Kolesterol Total Tikus Kelompok 2 Sebagai Kontrol Positif

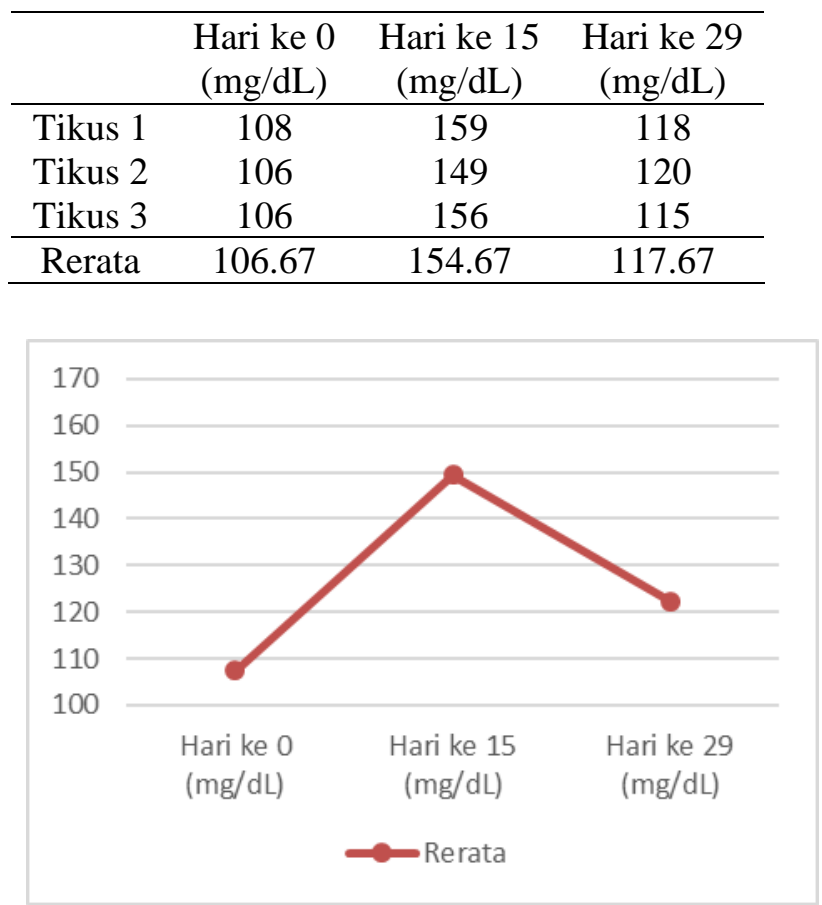

Gambar 2. Grafik Rerata Kadar Kolesterol Total Tikus Kelompok 2 
Suhendra, Awaloei, Wuisan: Uji efek ekstrak...

Tabel 3. Kadar Kolesterol Total Tikus Kelompok 3 Sebagai Perlakuan 1

\begin{tabular}{cccc}
\hline & $\begin{array}{c}\text { Hari ke 0 } \\
(\mathrm{mg} / \mathrm{dL})\end{array}$ & $\begin{array}{c}\text { Hari ke 15 } \\
(\mathrm{mg} / \mathrm{dL})\end{array}$ & $\begin{array}{c}\text { Hari ke 29 } \\
(\mathrm{mg} / \mathrm{dL})\end{array}$ \\
\hline Tikus 1 & 109 & 153 & 123 \\
Tikus 2 & 107 & 145 & 128 \\
Tikus 3 & 106 & 150 & 116 \\
\hline Rerata & 107.33 & 149.33 & 122.33 \\
\hline
\end{tabular}

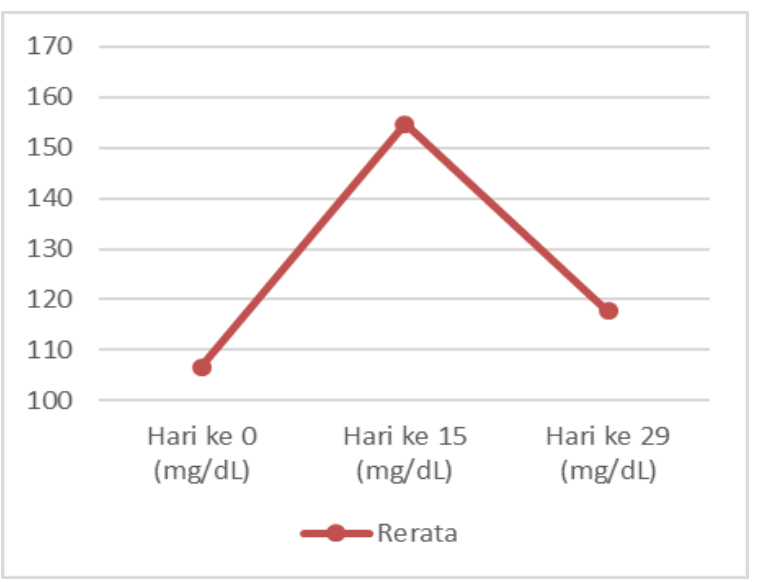

Gambar 3. Grafik Rerata Kadar Kolesterol Total Tikus Kelompok 3
Tabel 4. Kadar Kolesterol Total Tikus Kelompok 4 Sebagai Perlakuan 2

\begin{tabular}{lccc}
\hline & $\begin{array}{c}\text { Hari ke 0 } \\
(\mathrm{mg} / \mathrm{dL})\end{array}$ & $\begin{array}{c}\text { Hari ke 15 } \\
(\mathrm{mg} / \mathrm{dL})\end{array}$ & $\begin{array}{c}\text { Hari ke 29 } \\
(\mathrm{mg} / \mathrm{dL})\end{array}$ \\
\hline Tikus 1 & 105 & 160 & 107 \\
Tikus 2 & 107 & 149 & 109 \\
Tikus 3 & 108 & 153 & 102 \\
\hline Rerata & 106.67 & 154.00 & 106.00 \\
\hline
\end{tabular}

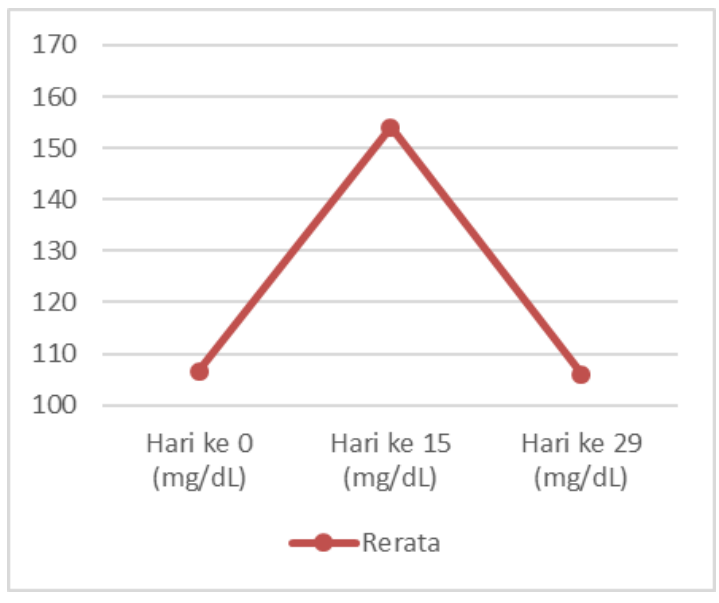

Gambar 4. Grafik Rerata Kadar Kolesterol Total Tikus Kelompok 4

Rerata kadar kolesterol total pada semua kelompok (kelompok 1, 2, 3 dan 4) dapat dilihat pada Gambar 5

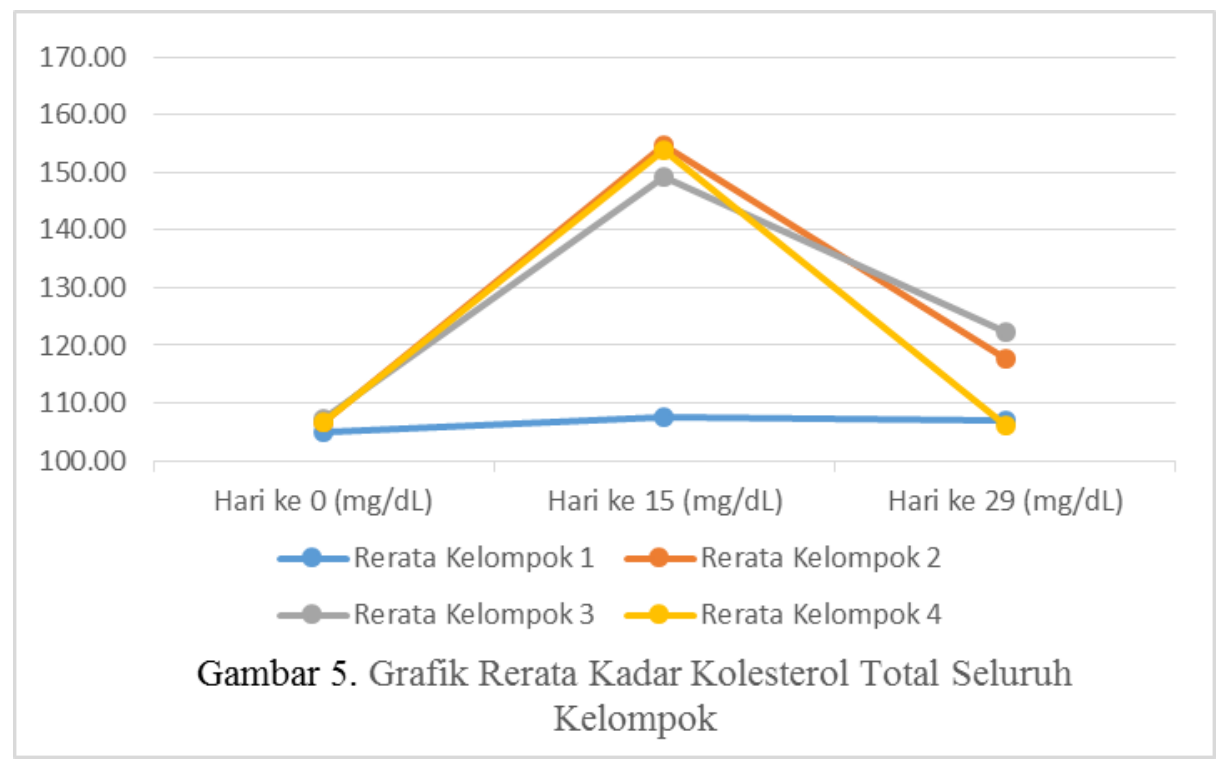




\section{BAHASAN}

Pada kelompok kontrol negatif hanya diberikan pakan standar (Pakan AD2) dan aquades tanpa diinduksi propiltiourasil (PTU) maupun diberi simvastatin dan ekstrak biji alpukat. Dapat dilihat bahwa kadar kolesterol total pada kelompok ini tidak mengalami perubahan yang signifikan walaupun tikus-tikus ini menunjukkan suatu perubahan kadar kolesterol total pada setiap kali pengukuran. Hal ini mungkin dipengaruhi oleh metabolisme masing-masing tikus yang berbeda.

Pada kelompok kontrol positif di penelitian ini, propiltiourasil (PTU) digunakan sebagai obat untuk menaikkan kadar kolesterol. Kadar kolesterol total seluruh tikus yang diukur sebelum diberikan PTU memiliki rerata 106,67 $\mathrm{mg} / \mathrm{dL}$, kadar kolesterol total seluruh tikus yang diukur pada hari ke 15 setelah diberi PTU memiliki rerata $154,67 \mathrm{mg} / \mathrm{dL}$ Setelah 14 hari pemberian PTU, dilanjutkan dengan pemberian simvastatin selama 14 hari. Didapatkan rerata kadar kolesterol total tikus pada hari ke 29 sebesar 117,67 mg/dL. Sesuai dengan teori yang disebutkan bahwa simvastatin menghambat enzim HMG CoA reduktase yang merupakan enzim prekursor pada pembentukan kolesterol sehingga menyebabkan penurunan daripada sintesis kolesterol dan selanjutnya akan menyebabkan kadar kolesterol total menurun. ${ }^{14,15}$

Pada kelompok perlakuan 1, tikus diinduksi oleh PTU selama 14 hari lalu dihentikan dan diberikan ekstrak biji alpukat dengan dosis $125 \mathrm{mg} / \mathrm{kgBB}$ tikus/hari selama 14 hari (hari ke 15 hingga ke 28). Kadar kolesterol total seluruh tikus yang diukur pada hari ke 15 setelah diberi PTU memiliki rerata 149,33 $\mathrm{mg} / \mathrm{dL}$. Hal ini disebabkan karena PTU yang diberikan pada tikus normal akan menyebabkan hipotiroidisme. Hipotiroidisme pada tikus akan menyebabkan peningkatan kadar kolesterol LDL sehingga kolesterol total akan meningkat. ${ }^{16,17}$ Rata-rata kadar kolesterol total tikus Wistar setelah diberikan 125 $\mathrm{mg} / \mathrm{kg}$ ekstrak biji Alpukat menurun sebesar $18,1 \%$. Kadar kolesterol total kelompok 3 mengalami penurunan yang cukup signifikan namun belum bisa menyaingi penurunan kadar kolesterol total pada kelompok 2 .

Pada kelompok perlakuan 2, tikus diinduksi oleh PTU selama 14 hari lalu diberikan ekstrak biji alpukat dengan dosis $250 \mathrm{mg} / \mathrm{kgBB}$ tikus/hari selama 14 hari. Rata-rata kadar kolesterol total tikus Wistar setelah diberikan $250 \mathrm{mg} / \mathrm{kg}$ ekstrak biji Alpukat menurun sebesar sebesar 31,2\%. Hal ini disebabkan karena kandungan antioksidan yang terdapat dalam biji alpukat, yaitu flavonoid. ${ }^{18}$ Flavonoid bekerja menurunkan kolesterol dengan cara mencegah perlengketan (plak) lipoprotein berdensitas rendah atau low density lipoprotein (LDL) di pembuluh darah dengan meningkatkan kinerja antioksidan seluler, yaitu paraoksonase. ${ }^{19,20}$ LDL yang tidak membentuk plak selanjutnya akan dibawa ke hepar untuk diekskresi melalui asam empedu. ${ }^{21}$

\section{SIMPULAN}

Berdasarkan hasil penelitian maka ekstrak biji alpukat dengan dosis 125 $\mathrm{mg} / \mathrm{kgBB}$ dan $250 \mathrm{mg} / \mathrm{kgBB}$ mempunyai efek dalam menurunkan kadar kolesterol total tikus Wistar yang telah diinduksi propiltiourasil.

\section{SARAN}

Perlu dilakukan penelitian lebih lanjut terhadap kandungan dari ekstrak biji alpukat untuk mengetahui komponen zat aktif yang paling berpengaruh pada penurunan kolesterol total.

Perlu dilakukan penelitian lebih lanjut mengenai pengaruh ekstrak biji alpukat terhadap kadar profil lipid lainnya yaitu triasilgliserol, HDL, dan LDL.

Perlu dilakukan penelitian lebih lanjut dengan dosis ekstrak biji alpukat yang lebih bervariasi sehingga dapat memperoleh dosis ekstrak biji alpukat yang berpengaruh terhadap penurunan kadar kolesterol total lebih jauh. 
Suhendra, Awaloei, Wuisan: Uji efek ekstrak...

DAFTAR PUSTAKA

1. Dewoto HR. Pengembangan obat tradisional Indonesia menjadi fitofarmaka. Maj Kedokt Indon. 2007;57(7):205.

2. Kementerian Kehutanan RI. Lokakarya nasional tanaman obat Indonesia. 22 Juli 2010. [diakses 23 Nov 2015]. Dapat diakses di:http://www.dephut.go.id/index.ph $\mathrm{p} /$ news/details/7043

3. Peoloengan M, Chairul, Komala I, Salmah S, Susan MN. Aktivitas antimikroba dan fitokimia dari beberapa tanaman obat. Seminar Nasional Teknologi Peternakan dan Veteriner. Balai Penelitian Veteriner. Bogor; 2006. p. 974.

4. Sari K. Pemanfaatan obat tradisional dengan pertimbangan manfaat dan keamanannya. Majalah Ilmu Kefarmasian. 2006;3(1):2.

5. Katno, Pramono S. Tingkat manfaat dan keamanan tanaman obat dan obat tradisional. Farmasi Universitas Gadjah Mada. Yogyakarta:Balai Penelitian Tanaman Obat Tawangmangu. 2002. p. 1-2.

6. Bergh B. The avocado and human nutrition I some human health aspects of the avocado. Proc of Second World Avocado Congress. Department of Botany and Plant Sciences, University of California. 1992:25-35.

7. Bergh B. The avocado and human nutrition II avocados and your heart. Proc of Second World Avocado Congress. Department of Botany and Plant Sciences, University of California. 1992:37-47.

8. Grant WC. Influence of avocados on serum cholesterol. California Avocado Society Yearbook. 1960;44:79-88.

9. Rodríguez JJG, Gómez RL, Rodríguez LMS, Garciglia RS, Zapata LCR, Zarzosa AO, et al. Antibacterial activity of defensin padef from avocado fruit (persea americana var. drymifolia) expressed in endothelial cells against escherichia coli and staphylococcus aureus. Hindawi Publishing Corporation. Biomed Res Int. 2013:1-9.

10.Olaniyan MF. Effect of liquid extract of pear avocado leaf (persea americana) on plasma levels of aminotransferases, cholesterol and total bile acid in hypertensive patients. Am J Med \& Med Sci. 2014;4(3):87-91.

11.Flores RG, Quintana CA, Licea RQ, Guerra PT, Guerra RT, Cuevaz EM, et al. Antimicrobial activity of persea americana mill (lauraceae) (avocado) and gymnospermae glutinosum (spreng.) less (asteraceae) leaf extracts and active fractions against mycobacterium tuberculosis. Am-Eurasian J of Sci Res. 2008;3(2):188-94.

12.Ozolua RI, Anaka ON, Okpo SO, Idogun SE. Acute and sub-acute toxicological assessment of the aqueous seed extract of persea americana mill (lauraceae) in rats. Afr J Trad CAM. 2009;6(4):573-8.

13.Camberos EP, Velázquez MM, Fernández JMF, Rodríguez SV. Acute toxicity and genotoxic activity of avocado seed extract (persea americana mill., c.v. hass). Hindawi Publishing Corporation. Sci World J. 2014:1-5.

14.Suyatna FD. Hipolipidemik. Dalam: Gunawan SG, Nafrialdi RS, Elysabeth. Farmakologi dan terapi. Edisi 5. Jakarta: Gaya Baru;2007. hal. 373-84.

15.Bersot TP. Drug therapy for hypercholesterolemia and dyslipidemia. In: Brunton LL, Chabner BA, Knollmann BC, editors. Goodman \& Gillman's The pharmacological basis of therapeutics. $12^{\text {th }}$ Edition. New York: McGraw-Hill;2011. p. 860-2.

16.Suherman SK, Elysabeth. Hormon tiroid dan antitiroid. Dalam: Gunawan SG, Nafrialdi RS, Elysabeth. Farmakologi dan terapi. Edisi 5. Jakarta: Gaya Baru;2007. hal. 441-3.

17.Brent GA, Koenig RJ. Thyroid and antithyroid drugs. In: Brunton LL, Chabner BA, Knollmann BC, editors. Goodman \& Gillman's The pharmacological basis of therapeutics. $12^{\text {th }}$ Edition. New York: McGraw-Hill;2011. p.1073-7.

18.Vinha AF, Moreira J, Barreira SVP. 
Jurnal e-Biomedik (eBm), Volume 4, Nomor 1, Januari-Juni 2016

Physicochemical parameters, phytochemical composition and antioxidant activity of the algarvian avocado (persea americana mill.). J Agric Sci. 2013;5(12):100-9.

19.Gross M. Flavonoids and cardiovascular disease. In: Pharmaceutical Biology. 2004;42:24-6.
20.Kumar S, Pandey AK. Chemistry and biological activities of flavonoids: an overview. Sci World J. 2013:1-6.

21.Voet D, Voet JG. Biochemistry: chapter 12 Lipid and membranes. Fourth Edition. New Jersey: John Wiley \& Sons, Inc; 2011. p. 386-457. 